\title{
LEGAL PROTECTION OF ANIMALS IN ISRAEL
}

\author{
Marine Lercier ${ }^{1}$
}

\section{TABLE OF CONTENTS}

I. Introduction to the animal protection dynamics in Israeli society

II. Religious and moral fundaments of animal protection in Judaism

III. Overview of the legislation on animals in Israel: cruelty, companions, experiments and wildlife

IV. Case law on animal cruelty in Israel

V. Further welfare concerns in Judaism and in the State of Israel

VI. The future of religious and legal consideration of animals: veganism?

VII. Conclusion on the current protection of animals in Israel

VIII. References

\section{Introduction to the animal protection dynamics in Israeli society}

The lawmakers of Israel have been promoting animal welfare and animal rights in an unprecedented way in recent years, irrespective of their political affiliation; they have united to increase the importance of cruelty to animals and animal suffering as a topic at the Knesse ${ }^{2}$ - where a Subcommittee for cruelty towards animals has been created ${ }^{3}$, and Animals Rights Day is marked with vegan dishes to be served to the Members of Parliament ${ }^{4}$ - in light of the Jewish religious and ethical values.

Animal defence organisations do not hesitate to use the opportunity laid down in the Animal Protection Law to refer animal abuse cases to the courts, with some even being taken to the Supreme Court of the State. Aside from Egypt, which

\footnotetext{
${ }^{1}$ Master in Animal Law and Society, UAB, 6th edition. Written in Barcelona, reviewed June 12th of 2017.

2 The Israeli Parliament. http://main.knesset.gov.il/Pages/default.aspx

3 http://knesset.gov.il/committees/eng/committee eng.asp?c id=577

${ }^{4}$ http://knesset.gov.il/spokesman/eng/PR eng.asp?PRID=11169
} 
inserted into its Constitution the principle of humane treatment of animals in 2014 and criminalized their mistreatment since 1937 , Israel ${ }^{5}$ is the only country in the Middle East to even possess animal anti-cruelty legislation and to regulate their welfare, from the early days of the State on.

Protests to end animal suffering have been taking place in Israel, particularly since the beginning of the 2010s, while activism started in the 1980 s and vegetarian campaigns in the 1990s, mostly in opposition to factory-farming and animal testing. More recently, a speech given by activist Gary Yourofsky on veganism and animal rights became one of the most watched videos of all time in Israel ${ }^{6}$. In the meantime, several undercover investigations led by Anonymous for the Animals Israel were broadcasted on major TV Channels such as Channel 2 and Channel $10 \mathrm{News}^{7}$, catching the attention of the public on a regular basis. On another hand, the 269life 8 movement spread internationally after activists in Israel began tattooing themselves after the number given to a rescued calf ${ }^{9}$. Other organizations and activist movements work hard to sensitise and educate the public by reporting, drafting, filing suits and holding protests, such as Let the Animals Live, Israel against Live Shipments, and CHAI, among others.

The biggest march for animal rights worldwide and in Israel history just took place in September 201710, with about 30000 people marching in downtown Tel Aviv to denounce the inhumane treatment of animals and calling for compassion, justice and veganism in Israel, with regards especially to live export of animals from Europe and Australia, the absence of a no-kill of stray animals policy, the lack of enforcement of anti-cruelty legislation, and the harm caused to animals in slaughterhouses ${ }^{11}$.

According to a survey led by the Economy Ministry, a third of Israeli households have pets, with 380000 dogs registered as a permit is mandatory, while

\footnotetext{
${ }^{5}$ https://www.globalanimallaw.org/database/national/egypt/

${ }^{6}$ « Best Speech Ever », Gary Yourofsky, https://www.youtube.com/watch?v=omweihtaYwI\&feature=youtu.be

${ }^{7}$ Investigation at Dabbach accessible at: https://anonymous.org.il/dabbach Investigation Soglowek accessible at: https://anonymous.org.il/soglowekpics ${ }^{8} \mathrm{http}: / / \mathrm{www} .269$ life.com/\#\&panel1-1

9 " The Israeli Calf that started a Mass Tattoo Movement », by Netta Ahituv, March 21st, 2013, Haaretz, accessible at:

http://www.haaretz.com/israel-news/the-israeli-calf-that-started-a-mass-tattoo-movement.premium1.511045

${ }^{10}$ Records from the march accessible at: https://www.youtube.com/watch?v=Ul0RYK-9BqE.

${ }^{11}$ « Thousands flock to mass Tel Aviv rally for Animal Rights », by Daniel K. Eisenbud, September 10, 2017, The Jerusalem Post, accessible at: http://www.jpost.com/Israel-News/WATCH-Thousands-flockto-mass-Tel-Aviv-rally-for-animal-rights-504657
} 
no exact numbers can be found regarding cats, yet they are estimated to be about $260000^{12}$. Yet feral cats are everywhere in Israel.

As for the animals kept by the food industry, there is one hen per citizen in Israel, meaning, in the words of Avraham Pinkas ${ }^{13}$ - founder of Hai-Meshek, an Israeli organization preventing the cruelty against animals who launched successful campaigns - that every person is responsible for the treatment inflicted upon this animal. The rationale is that, in such a small country, people can choose to free laying-hens from their cages by buying free-range and thus improve their welfare, and the organization created a label to ensure the living conditions of free-range laying hens ${ }^{14}$, as battery-cages have not been forbidden yet in the country despite their horrible reality ${ }^{15}$.

Similar campaigns could be launched regarding other animal issues, such as the gestation of pigs still confined in crates under no prohibition, and certainly to improve the welfare of milking cows as well, regarding the fact that Israel has one of the highest dairy production rates per capita in the world ${ }^{16}$.

Having briefly introduced the dynamics of animal protection in the Israeli society, I will first investigate the religious and moral fundaments of animal protection that can be found in Judaism (I). These foundations have inspired the legislation on animals in Israel (II) as a tool for interpretation and evolution in the application of the norms, especially in animal cruelty cases, as credited by the courts (III). Secondly, while demonstrating that the basis for animal protection and care is strong in Jewish tradition and progress has been made, I will reveal that there is still much to be done as regards serious welfare issues particular to Judaism and Israeli society (IV). Nonetheless, given Israeli society activism and involvement in denouncing animal abuse, and religious roots for veganism and respect for animals, I believe that we can hope for a vegan future (V) as Israel is already home to the highest number of vegans per capita, and to promising research to provide alternatives to intensive farming and the breeding and killing of animals.

\footnotetext{
12 «In Israel, Man's best friend is also his most expensive friend », by Hadar Kane, January 6, 2017, Haaretz, accessible at: https://www.haaretz.com/israel-news/business/1.763359

${ }^{13}$ See Hai Meshek's videos:

https://www.youtube.com/watch?v=fx3FbpYLOno https://www.youtube.com/watch?v=82Lh6by8EPs

${ }^{14}$ See Hai Meshek's website: http://www.hai-meshek.org.il/?page_id=335

15 The Brutal Reality Behind Israel's Egg and Poultry Quotas, by Orna Rinat, December 29th, 2015, Haaretz, accessible at: http://www.haaretz.com/opinion/.premium-1.694293

16 The Land of Milk: Israel's Super Cows are the World's Most Productive, by Joshua Levitt, March 11th, 2014, The Algemeiner, accessible at: https://www.algemeiner.com/2014/03/11/the-land-of-milk-israels-super-cows-are-the-worlds-mostproductive-video/
} 


\section{Religious and moral fundaments of animal protection in Judaism}

\section{i. From the holy texts}

The most fundamental connection between human beings and animals is found in the first chapters of the Torah. Indeed, Adam had the responsibility to name animals ${ }^{17}$ and all non-human and human animals are even meant to have been speaking the same language before the original $\sin ^{18}$. In the very beginning, despite the Animal Kingdom as believed to have been placed under the dominion of Man who was given permission to employ animals in useful services, meat-eating was not permitted. Adam and Eve did not, as a matter of fact, eat meat, according to Jewish tradition; thus, the Torah implies the ideal human diet is vegetarianism, making what we eat a matter of primary concern from the very moment of the Creation $^{19}$. Also, Genesis emphasizes the link between humanity - adam - and the earth - adamah.

The story of Noah's ark was a fundamental episode and turning-point regarding the relationship between human and non-human animals, as only after punishing Man's behaviors did God decide to allow humans to eat animals within the Seven Laws - known as the Noahide laws - due to Man's supposed intrinsic weakness. As a consequence, only after the Flood has Man been given the limited « right » to kill animals for food, providing there is such need and it is done in the most humane way possible.

The principle of tsaar ba'alei chayim, prohibiting unnecessary pain to animals, was laid down by the Torah over than 3000 years ago; there is consequently a biblical limit to Man's cruelty and use of animals for human need found in the prohibition of cutting a limb off a living animal, later on understood more broadly as prohibiting unnecessary cruelty and undue cruel slaughter ${ }^{20}$.

\footnotetext{
${ }^{17}$ Now the Lord God had formed out of the ground all the wild animals and all the birds in the sky. He brought them to the man to see what he would name them; and whatever the man called each living creature, that was its name.

So the man gave names to all the livestock, the birds in the sky and all the wild animals. Genesis 1:1

${ }^{18}$ Now the serpent was more crafty than any of the wild animals the Lord God had made. He said to the woman, "Did God really say, 'You must not eat from any tree in the garden'?"

The woman said to the serpent, "We may eat fruit from the trees in the garden, but God did say, 'You must not eat fruit from the tree that is in the middle of the garden, and you must not touch it, or you will die." "

"You will not certainly die," the serpent said to the woman. "For God knows that when you eat from it your eyes will be opened, and you will be like God, knowing good and evil." Genesis 1-3

${ }^{19}$ And God said: "Behold, I have given you every herb yielding seed which is upon the face of all the earth, and every tree that has seed-yielding fruit—-to you it shall be for food." Genesis 1:29

${ }^{20}$ Every moving thing that liveth shall be meat for you; even as the green herb have I given you all things. But flesh with the life thereof, which is the blood thereof, shall ye not eat. Genesis 9:3-4
} 


\section{dA derecho ANIMAL la web center de los animales con derecho}

\section{ii. From the rabbinic interpretation}

One of the most famous Jewish scholars of the $12^{\text {th }}$ century Orthodox movement, Maimonides ${ }^{21}$, considered animals to exist for their own sake, and independently of Man, because they were created by God's will. He further considered there was no difference between the pain of Man and this of other living creatures. An interesting perspective and a topic contemporary interest is his teaching of the restriction of killing the offspring in the sight of its mother, based on the indistinguishable feelings of love and tenderness that both human and non-human animals share towards their young: such a scene would unambiguously convey extreme pain, and has led to the Jewish prohibition of killing a mother and its offspring on the same day.

Another very interesting element is the perspective on the extinction of species. From a Jewish point of view, it is not permitted to bring an entire species to extinction, according to Nachmanides ${ }^{22}$, based on the idea that nothing is deemed to have been created in vain, according to the Talmud. Reform Judaism, for its part, considers that dominion over animals comes with an obligation to protect all of God's creatures, as they all have intrinsic value, also supported by the views of Maimonides. Notably, the concept of tikkun olam, which means healing the world, and is very important to Reform Judaism, implies supporting the protection of endangered species and their habitats. Moreover, it considers the duty of care to domestic animals to be a moral obligation.

On the other hand, hunting is considered by the three movements as being a violation of Jewish ethical codes, such as the principles of tsaar ba'alei chayim and bal tashchit ${ }^{23}$, as well as a cruel and wasteful sport.

Conservative Judaism highlights another interesting example of mercy to animals, in line with the contemporarily researched and established link between cruelty to and violence directed towards animals, and the subsequent or concomitant violent behaviour of humans ${ }^{24}$. Indeed, according to this theory,

\footnotetext{
${ }^{21}$ Moses Maimonides, A Guide for the Perplexed, translated from the original Arabic text, 1186, by M. Friedlaender, 4th revised ed., New York: E.P. Dutton, 1904,

${ }^{22}$ Nachmanides was also a Spanish scholar, from the 13th century and died in the Holy Land after having been expelled from Spain.

${ }^{23}$ i.e. the law prohibiting waste.

${ }^{24}$ There is abundant literature relevant to the subject as reviewed by PETA:

https://www.peta.org/issues/companion-animal-issues/companion-animals-factsheets/animal-abusehuman-abuse-partners-crime/

and the HSUS notably:

http://www.humanesociety.org/issues/abuse neglect/qa/cruelty_violence_connection_faq.html?referrer=h ttps://www.google.es/
} 
compassion towards animals would promote piety and prevent human beings from behaving cruelly towards each other.

\section{Overview of the legislation on Animals in Israel: cruelty, companions, experiments and wildlife}

The Minister for the Environment ${ }^{25}$ and in particularly the Minister for the Agriculture are principally in charge of the protection of animals in the State of Israel26; it was decided that the latter would continue to be the one enforcing animal welfare legislation amid concerns from activist groups of a possible conflict of interest, and accusations of negligence in its implementation ${ }^{27}$. The Minister for the Agriculture is in charge of enacting regulations concerning the keeping of animals (as much farm animals as pets in shops), the conditions of transporting animals, the means of killing animals (except for the slaughter for food), training animals and animal exhibitions.

We will provide an overview of anti-cruelty legislation structure, provisions and enforcement (1) with a focus on cats and dogs protection in Israel (2) and the state of animal experimentation (3) before mentioning wildlife protection measures (4) and draft bills seeking approval before the Knesset in the near future (5).

\section{i. Anti-cruelty legislation and general animal protection framework}

The Animal Protection Law on Cruelty to Animals, 5754, was passed by the Knesset on 28 Tevet $^{28}$ which CHAI (Concern for Helping Animals in Israel), an Israeli animal welfare organization ${ }^{29}$, helped to draft. It lays down main prohibitions towards animals and the punishment of the breach thereof. This is the main piece of Israeli legislation regulating the treatment of animals. The same year, a second Animal Protection Law on Animal Experimentation was enacted. Both were initiated by Member of Knesset Abraham Poraz.

\footnotetext{
If you want to stop violence against people, Stop violence against animals, by Lynne Peeples, August 10th, 2015, The Huffington Post:

http://www.huffingtonpost.com/entry/animal-abuse-human-violence-link_us_560f2269e4b0af3706e0fd5b

${ }^{25} \mathrm{http} / / / \mathrm{www}$. sviva.gov.il/English/Pages/HomePage.aspx

${ }^{26}$ http://www.moag.gov.il/Pages/HomePage.aspx

27 Animal Welfare Enforcement to Remain in Agriculture Ministry, by Sharon Udasin, December 14th,

2015, The Jerusalem Post, accessible at:

http://www.jpost.com/Israel-News/Animal-welfare-enforcement-to-remain-in-Agriculture-Ministry437247

$\frac{437247}{28} 11$ January 1994

${ }^{29}$ See CHAI's website:http://www.chai-online.org/
} 
The Law on Cruelty to Animals describes in very simple words that which is to be forbidden towards animals - preferable to using ambiguous terms to refer to cruel treatments. Thus it appears to be a broad yet efficient text aimed at regulating a wide range of human behaviors towards all animals, under all circumstances, according to the text.

Animal use for experimentation is nonetheless excluded from the application of the State anti-cruelty legislative provisions, but is covered by particular regulations. Also excluded is the slaughter of animals for the purposes of food for humans, as they obey other commandments, and the legislator does not want to interfere with neither Jewish nor Muslim ritual slaughter. Lastly, slaughter of animals concerned with specific regulations of the Rabies and Animal Diseases ordinances of 1934 and $1985^{30}$ is excluded for the general interest of the State to prevent and eradicate zoonoses. Yet these ordinances ought to be amended, as they cannot be read in any way other than the outdated notion that animals are regarded pests and treated as such - without much consideration; more balance would be welcome in the means for human health protection as an end.

The anti-cruelty law stipulates, under Section 2, that (a) «no person shall torture, treat cruelly or in any way abuse any animal »; (b) «no person shall incite one animal against another »; (c) "no person shall organize a contest between animals» making it clear that animal fighting and any other sport or competition involving animals is strictly forbidden ${ }^{31}$; and (d) " no person shall cut into a live tissue of an animal for cosmetic purposes » prohibiting animal vivisection for teaching purposes in classes, and practices such as cropping the ears and tails of purebred dogs since 2001, as well as tattooing further to 2015 amendment. However, as another particular law has been designed specifically to regulate experimentation on animals, this anti-cruelty law does not apply to animals in laboratories used for experimentation.

The law goes on to protect animals used for work, following the traditional view that Man can use animals to help him when carrying out useful tasks, as both have evolved to cooperate through and benefit from working relationships due to their mutual needs. It aims to ensure that Man respects the natural limitations imposed upon the animal, resulting in care for its physical condition, and must be accounted for when prohibiting unfit animals to work. Working any animal to exhaustion is equally forbidden under Section 3. This provision is particularly

\footnotetext{
${ }^{30}$ Rabies ordinance, 1934, accessible at: http://extwprlegs1.fao.org/docs/pdf/isr20790e.pdf

Animal Diseases ordinance, 1985, accessible at: http://extwprlegs1.fao.org/docs/pdf/isr21179.pdf

${ }^{31}$ For example, there is not and has never been in Israel horse racing or dog racing, nor bullfighting.
} 
impregnated with Jewish spirit, as, for example, it requires that animals rest on Shabbat, just like Man must.

The scope of the law does not privilege one category of animals over the other; companion animals, captive animals, farm and wild animals are entitled the same level of protection through a system of prohibition of human behaviors.

The law mentions also the interdiction of killing by poison, notably quoting strychnine, a neurotoxin which toxicity is known especially for birds, cats, dogs, mice, rats, rabbits and other small vertebrates, killing them by muscular convulsions leading to asphyxia, particularly painful and cruel. An exemption applies to veterinarians killing animals through means of poison for prevention of rabies and other zoonoses under authorization and control of the Veterinary Services of the Ministry of Agriculture according to the Rabies and Prevention of Animal Diseases ordinances.

The law establishes powers to search and investigate any offense under the Law in Section 6, in which case, according to Section 8, the animal can be seized as a protective measure when it is suspected that abuse has been committed. Section 13 stipulates that, should the state of an animal justify the need to end its sickness or suffering, euthanasia should be carried out without causing unnecessary suffering, essentially meaning, in the most humane way possible.

Moreover, Section 15 institutes the right for animal protection organizations duly approved by the Minister for the Environment to file complaints regarding offenses to the law, i.e. cruelty to animals: they have standing. There is no such issue as legal standing as far as animal defence organizations are concerned in Israel; organisations are entitled to defend the interests of animals in the courts whether it is a civil, administrative or criminal process. These offenses are punishable by up to 4 years imprisonment for cruel treatment (section 2), and up to 1 year of imprisonment for breaching the prohibition on working animals (section 3) or poisoning (section 4), coupled with fines of up to NIS $226000^{32}$, following an amendment to the Animal Protection Law in December 201533. Progress was heavily welcomed by civil society, as well as Members of the Knesset and government, with the Jerusalem Post even, although perhaps mistakenly, speaking of « stricter animal rights measures ».

Covering the main areas pertaining to the protection of animals, section 14 again establishes a Fund for Animals in charge of the education, information, training

\footnotetext{
${ }^{32}$ About 57000 euros as of June 12th, 2017.

${ }^{33}$ Knesset passes stricter animal rights measures: more jail time, increased fines for violators, by Sharon Udasin, December 15th, 2015, The Jerusalem Post, accessible at: http://www.jpost.com/Israel-News/Politics-And-Diplomacy/Knesset-passes-stricter-animal-rights$\underline{\text { measures-More-jail-time-increased-fines-for-violators-437396 }}$
} 
and assistance regarding animal cruelty issues. Moreover, when punishment is decided but does not amount to prison for an offense committed under the Law on Protection of Animals, the fine granted is systematically given to the Animal Fund with the objective of promoting the purposes of this law.

Significantly, the Knesset amended the Law in 2015 to establish the duty of care of the animal's guardian, as well as a provision for the basic needs of an animal as a question of welfare ${ }^{34}$, ensuring that abandonment can result in sanction when perpetrated by non-owners also: the law is to be applied both to the owner and to the holder of the animal, regardless of ownership. Additionally, there is a clause adding that shelters have the obligation to spay and neuter their animals before putting them up for adoption.

In addition to this, another new and major provision was introduced by the 2015 amendment, singling out the responsibility of senior executives of corporations that handle animals, such as slaughterhouses, obliging them to do everything in their power to prevent abuse against animals, and emphasizing their responsibility of supervising animal welfare from the top down; this put the burden on the executive to prove that they did everything they could to prevent cases of abuse. Promoter of the amendment, MK Itzik Shmuli from the Zionist Union, said the next aims was to extend this responsibility to the managers of such corporations.

After the approval of the first reading of this amendment, Dov Lipman, from the Yesh Atid party, acknowledged that there is a spirit of change in the air regarding progress on preventing the suffering of animals in Israel, highlighting that: "We now have an agricultural minister, Uri Ariel, who truly cares about the issue and, as this law shows, he plans to take action, (while) the current public security minister, Gilad Erdan, is someone who (...) will, without a doubt, be strict with enforcing the laws in this realm. This creates a real window of opportunity for real progress on this important Jewish and human value. »35

\section{ii. Companion and stray animals: cats and dogs legislation}

On another hand, the Dog Regulation Law of 2002 regulating the guardianship of dogs asserts that all dogs must be licensed, micro-chipped and vaccinated annually against rabies ${ }^{36}$, while the Prohibition on Declawing Cats of

\footnotetext{
${ }^{34}$ https://knesset.gov.il/spokesman/eng/PR_eng.asp?PRID=11818

${ }^{35}$ Knesset approves strict amendments to animal welfare law in first reading, by Sharon Udasin, July 28th, 2015, The Jerusalem Post, accessible at:

http://www.jpost.com/Israel-News/Knesset-approves-strict-amendments-to-Animal-Welfare-Law-in-firstreading-410426

${ }^{36}$ Main pieces of legislation and regulations can be accessed from the SPCA platform at http://spca.co.il/newsite/page en.asp?p id=41
} 
$2011^{37}$ forbids onychectomy ${ }^{38}$ - amounting mutilation or amputation - unless it is vital for the health of the animal or its owner, imposing a $20000 \$$ fine and up to a year of prison on violators.

The question of animal spaying and neutering is a hot topic among Israeli society, not only because it made it to questioning the religious validity of such procedure ${ }^{39}$, but mostly because of the serious overpopulation and predicament of stray animals in the country, calling for more effective measures to manage the street population.

Following a pilot project conducted by Israel's Ministry of the Environment in 2005, several municipalities in Israel have provided all or part of the funding for trap/neuter/vaccinate/release (TNR) programs for feral cats. In 2007, government officials proposed a law providing such funding throughout the country ${ }^{40}$. In 2013, Agriculture Ministry launched a 4.5 million shekels program to spay and neuter 45 000 stray cats in cooperation with local authorities ${ }^{41}$ - a number insufficient regarding the wide population of cats in Israel, representing a serious animal welfare issue as street cats results in cats suffering. Cat overpopulation is notably accounted to be due partly to the massive import of cats to deal with rat infestation under the British mandate, coupled with the warm climate allowing cat females to have up to 3 litters a year. In comparison with official estimations, cats activists estimate there are up to 2 million stray cats in Israel $^{42}$.

Israel recently decided to allocate a 4.5 million shekels budget ${ }^{43}$ yet only to the spaying and neutering of stray dogs to avoid putting thousands down as means to reduce dog population and the risk of diseases, leaving stray cats behind ${ }^{44}$. The adoption of the bill was motivated by the consideration that in the long run, it will cost less to manage the population through spaying and neutering than maintaining kennels and putting healthy animals to sleep, the cost of which is estimated to be around 33 million shekels a year.

\footnotetext{
37 «In Israel, declawing your cat could get you jail time », by Erin Skarda, December 9th, 2011, Time, accessible at:

http://newsfeed.time.com/2011/12/09/declawing-your-cat-could-get-you-a-year-in-jail-in-israel/

38 i.e. declawing cats.

39 « Ask the Rabbi: neutering animals », by Schlomo Brody, May 14, 2009, The Jerusalem Post, accessible at: http://www.jpost.com/Jewish-World/Judaism/Ask-the-Rabbi-Neutering-animals

40 «Feral cats in Israel », CHAI Factsheet, accessible at:

http://www.chai.org.il/en/companion/overpopulation_feral.htm

${ }^{41}$ « Israel plans mass spaying campaign to combat street cat proliferation », by Sharon Udasin, October

28, 2013, The Jerusalem Post, accessible at: http://www.jpost.com/Enviro-Tech/Israel-plans-massspaying-campaign-to-combat-street-cat-proliferation-329973

42 « Scrambling every day: Stray cats struggle to survive in Jerusalem », by Derek Stoffel, August 27 ,

2016, CBC News, accessible at: http://www.cbc.ca/news/world/jerusalem-stray-cats-1.3732282

${ }^{43}$ About 1.25 million \$.

44 «In groundbreaking move, Israel creates budget to fix stray dogs rather than putting them down », by

Jonathan Lis, March 22, 2017, Haaretz, accessible at: https://www.haaretz.com/israel-news/1.778818
} 


\section{iii. Animal experimentation}

Along with the Animal Protection Law on Cruelty to Animals, the Animal Protection Law on Animal Experiments of 5754 regulates experiments involving animals in Israel. It is based on voluntary guidelines set by the Academy of Sciences and Humanities. Since 2007, experimentation on animals for cosmetic and household cleaning purposes are banned, but surprisingly any other experiment is allowed without any review or authorization process other than that of the company itself, which obviously does not impose any serious limitation or monitoring on the experimentation on animals. Nonetheless, Israel decided, as of January 1st of 2013, to no5 import and sell cosmetics and detergents tested on animals any longer ${ }^{45}$, which is a good step forward.

\section{iv. Wild animals protection and biodiversity conservation}

Furthermore, the recognition of the need to protect Israel's exceptionally diverse biodiversity led to the enactment of laws for the protection of nature, assets and wildlife and their habitats. Animals such as leopards, gazelle, ibex and vultures have been declared protected species, with projects being initiated to reintroduce animal species in wildlife reserves. Although Israel has never had a whaling industry, it also joined the International Whaling Commission in order to vote against any resumption of commercial whaling.

The Wildlife Protection Law 571546, which has the purpose of protecting species rather than individual animals, includes welfare provisions such as the banning of hunting and catching animals with traps, snares and nets, and poison, and introduces CITES $^{47}$ into Israeli domestic legislation also. The Law regulates hunting in such a way that a license and express permit are required, and permitting it only for scientific purposes, reproduction, maintaining balance in nature, preventing damage to agriculture or danger to humans or animals and to prevent infectious diseases: hunting cannot be a sport.

In the same order of ideas, the National Parks, Nature Reserves, National Sites and Memorial Sites Law $5752^{48}$ instituted national parks, defined as an area serving the preservation of nature among others, and nature reserves ${ }^{49}$ defined as « an area

\footnotetext{
${ }^{45} \mathrm{http}$ ///www.peta.org/blog/israel-bans-animal-tested-products/

46 1955, amended in 1999.

חוק להגנת חיית הבר, התשט"ו

http://extwprlegs1.fao.org/docs/pdf/isr14268.pdf

${ }^{47}$ https://www.cites.org/eng/disc/text.php

${ }^{48} 1992$.

${ }^{49}$ There are more than 150 nature reserves according to the Minister of Foreign Affairs, see: http://mfa.gov.il/MFA/IsraelExperience/AboutIsrael/Spotlight/Pages/Nature\%20Conservation\%20in\%20I srael.aspx
} 
in which animals, vegetation, abiotic objects, soil, caves, water or landscape, which are of scientific or educational interest, are preserved from undesirable changes in their appearance, in their biological composition or their development process " to be declared by the Minister of the Interior, and established the protection of natural assets regarding their worth or danger of extinction. Notably it lays down the prohibition to cause damage or bother an animal, to alter the shape or natural position of animals, to interfere with their reproduction, with the breach thereof being punishable by between 6 months and 3 years imprisonment.

Finally, the Fisheries Ordinance of 1937 pre-State Law, consolidated in 2000, establishes a license system and minimum requirements regarding the sizes and methods of fishing, some of which are forbidden. In particular, there are two protected species (blind shrimp and marine turtles) of which fishing is strictly prohibited.

\section{v. Further developments and draft bills}

Additionally, Member of Knesset Nitzan Horowitz has introduced a bill towards banning fur that he has unsuccessfully been trying to pass since 2009 with wide public, religious and political support ${ }^{50}$. Israel could become the first country in history to forbid not only the raising of animals for fur, but also the mere selling of it.

\section{Case law on animal cruelty in Israel}

Only a few cases of institutionalized animal cruelty have been brought to court. The need to protect animals was stated by the court to constitute a part of Jewish culture, with an obligation to protect every living being created on this planet ${ }^{51}$.

The Supreme Court of Israel has long adopted a cost and benefits approach, balancing the interests of the protagonists at stake - which could reveal itself to be an incredible step towards the upholding and advancement of animal rights if used strategically - that we will envision through the «Crocodile » (1) and «Foie Gras » (2) cases. Modern Israeli legislation concerning animals adopts the balancing principle, which is reflected in the case law relative to the treatment of animals.

\section{i. The « Crocodile case »}

\footnotetext{
${ }^{50} \mathrm{http}: / / \mathrm{www}$.peta.org/blog/are-dirty-politics-holding-up-ban-on-fur-in-israel/

${ }^{51}$ The Cat Welfare Society of Israel v. Municipality of Arad, Supreme Court of Israel, 1996, HCJ $6446 / 96$.
} 
In 1997, the Jerusalem-based Court could ban human fights with crocodiles on the grounds that the cost of suffering to the animal outweighed the (questionable) benefit of entertainment ${ }^{52}$. "Alligator's Battle Against Man » was judged to be crossing the boundaries of the Animal Protection Law on Cruelty to Animals prohibition under Section 2, with the lower court determining that « it is absolutely clear that that the performance causes the alligator physical suffering, since it involves the use of much force, pressure, pulling, dragging, and shaking. Furthermore, throughout the show, the alligator is forced into unnatural, violent, and frightening movements, which may even be harmful.» to conclude in first instance that the performance did indeed cause grave physical suffering and stress, hence finding it contrary to the provisions set out in Section 2 without the financial gain of the show being a sufficient ground for performing such behaviour, reinforced by the fact that « Financial gain simply does not justify cruelty. » Yet the lower court's ruling was overturned by the District Court on grounds of a failure to satisfy the burden of proof relying on the petitioner - animal defence organization Let the Animals Live53.

In order to interpret meaningfully the terms « torture » (inui), « cruelty » and " abuse », the Supreme Court turned to the criminal law definition of abuse of minors or helpless persons ${ }^{54}$ combined with biblical references from Exodus, Deuteronomy, Genesis and Samuel regarding "torture ", from Jeremiah and Isaiah to define « to treat cruelly » (lehitahzar), and from Samuel, Judges and Jeremiah to define « abuse » (hitolelut).

As part of the judgment, a three-stage test was set out to determine whether an act is proscribed by law: firstly, the act has to be such that it would be seen by a bystander as constituting either torture, cruelty, or abuse; secondly, the extent of pain or suffering caused to the animal are appreciated widely, so as to there no requisite of especially great suffering; thirdly, the means that cause the suffering must be disproportionate to the purpose for which they are employed to constitute animal abuse.

The first judgement confirmed that, as the third element of the test - the show's purpose - was to entertain the audience, the value at stake was not one that justified the suffering of the crocodile, meaning it was disproportionate to cause suffering to an animal for the mere purpose of entertainment, while other means that do not involve animal abuse are available. It would be ideal that such reasoning

\footnotetext{
${ }^{52}$ Let the animals live v Hamat Gader Recreation Enterprises, Tony Loten, Kibbutz Afik, Kibbutz Meitar, Kibbutz Mavo Hama, Kibbutz Kfar Haruv, Court of Civil Appeals, June 22nd, 1997.

${ }^{53} \mathrm{http} / / / \mathrm{www}$.letlive.org.il/eng/

${ }^{54}$ As set by section 368 (c) of the Criminal Law.
} 
be applied in case challenging the necessity and proportionality of causing animals to suffer for food production, following the example of the Foie Gras case.

\section{ii. The « Foie Gras case »}

There are an ever-increasing number of vegans among secular, as well as Conservative, Reform and Orthodox Jews that, in spite of a wide-range of considerations, all converge to the same conclusion: that exploiting animals and treating them cruelly is wrong. This, in addition to the balance of interests legal approach, provided for another major victory for animal welfare in 2003. Presented with the question « does force-feeding constitute torture, cruelty, or abuse? »55 the Supreme Court ruled that the production of foie gras was illegal as it violated the provisions of the Animal Protection Law on Cruelty to Animals Section 2, when applying the test designed in the Crocodile case.

Justice E. Rivlin said:"As for myself, there is no doubt in my heart that wild creatures, like pets, have emotions. They were endowed with a soul that experiences the emotions of joy and sorrow, happiness and grief, affection and fear. Some of them nurture special feelings towards their friend-enemy: man. Not all think so; but no one denies that these creatures also feel the pain inflicted upon them through physical harm or a violent intrusion into their bodies. Indeed, whoever wishes to may find, in the circumstances of this appeal, prima facie justification for the acts of artificial forcefeeding, justification whose essence is the need to retain the farmer's source of livelihood and enhance the gastronomic delight of others.... But this has a price - and the price is reducing the dignity of Man himself. »56

The Court reasoned as follows, applying the test of animal cruelty to the production of foie gras: first, to a bystander, this process constituted torture, cruelty, or abuse; second, it is scientifically proven that force-feeding animals causes suffering; third, the means used are disproportionate to the purpose of enlarging the liver of the animal beyond its normal size, to produce food for human consumption. Nonetheless, the Court did state that food production is a more important purpose than entertainment, thus to be appreciated with more scrutiny. Moreover, the fact that force-feeding is the only way of producing foie gras most likely strengthened the claim for its prohibition.

The Court defined this to be a case about the way that animals are raised; taking this further, it would have ramifications for other agricultural methods used

\footnotetext{
55 The meaning of these terms was defined in the aforementioned decision.

${ }^{56}$ Foie Gras Verdict, Supreme Court of Israel, August 2003, accessible at: http://www.chai.org.il/en/compassion/foiegras/foiegras.pdf
} 
to raise animals for food consumption. This was the opportunity for the Court to specifically mention calf meat (veal), which requires the raising of the calf in a specific way so that they lack iron, thus giving the meat a pale color, as well as the forced molting of feather from or starving hens to increase their egg production. We can assume that these will be the next targets of the Court, if appropriately presented with these issues by a coalition of animal defence organizations. The Court, indeed, acknowledged the shift in attitudes toward animals that finds expression in new legislation, prohibiting certain uses of animals, and directed towards bettering the conditions in which they are raised.

Even though it took time for the State to enforce the verdict, as the Court took into account the need for farmers to reorganize and foresaw the consequences of outlawing a practice from one day to the other, by providing the industry with a transitional period to adapt to the ruling, the Supreme Court ordered the State to do so again in 2006, and the ban is came into force from then onward. According to the theory of relative invalidity, the court could modulate the consequences of the annulment by deciding the time of its entry into force, as its effects can either be retroactive, immediate, or prospective.

Before the ban, some limitations applied to force-feeding through the Cruelty to Animals regulations on geese force-feeding of $2001^{57}$ that included freezing the industry, i.e. prohibiting opening new establishments or expanding existing ones. Since 2013, it has been forbidden to import and sell foie gras in the State of Israel58, as its production methods amount to animal cruelty. This is a major step in acknowledging and working towards minimizing and ending animal suffering, as Israel was one of the major foie gras producers and exporters in the world.

\section{Further welfare concerns in Judaism and in the State of Israel}

Sadly, there is still no ban on confining hens in battery cages in Israel, nor of dehorning without anaesthesia. The main problem lies with abuses taking place in slaughterhouses (2) and the shipments of live animals to be slaughtered (3), coupled with the suffering inherent in the ritual slaughter under kashrut ${ }^{59}$ and religious sacrifice customs (1).

\section{i. Animal sacrifice}

\footnotetext{
${ }^{57} \mathrm{https} / / / \mathrm{www}$. animallaw.info/sites/default/files/stisreal_geese_force_feeding.pdf

${ }^{58}$ https://www.knesset.gov.il/spokesman/eng/PR_eng.asp?PRID=10824

${ }^{59}$ The kashrut is the system of dietary rules, a mitzvah to be fulfilled by Jewish people. for example, land animals must have cloven hooves and chew their cudd; fish must have fins and scales, amongst others. also, it requires the separation of meat from milk.
} 
Yom Kippur is the day of atonement in Judaism and considered the holiest day when Jews fast, pray and repent 60 . On this day, an old and controversial custom takes place: the kaparot, where one swings a chicken over one's head as a sign of penance to transfer Man's sins to the animal, that is then slaughtered and traditionally given to charity. It has been opposed by Sages for centuries and being given particular consideration recently ${ }^{61}$.

It is only practiced in traditional communities, yet can still understandably be regarded as animal cruelty by some, as people seem to be more outraged by the killing of animals for religious purposes, even though in way smaller numbers once a year, than they can be by the every day huge number of animals killed in slaughterhouses for food; all acts of killing the animals should be judged on the same level when it comes to assessing their " necessity », and it is unjustified to assert that it is "more » necessary to kill animals for food than for religious observance; everyone is free to replace the animals in both situations.

Israel's Ministry of Agriculture launched a powerful campaign last year before Yom Kippur to leave the chickens alone by encouraging people not to perform kaparot with the slaughter, but only by donating money to the poor on this holiest day of the year, using a cartoon video featuring a chicken fighting for its release ${ }^{62}$. Three cities in Israel have already banned the performance of kaparot in public places: Tel-Aviv, Petah Tikva and Rishon Letzion63.

\section{ii. Animal Slaughter}

In spite of Jewish law stipulating that animals may be eaten providing they are humanely slaughtered, ritual slaughtering remains painful even though Jewish authorities determined shehita ${ }^{64}$ as being the least painful method of slaughter after

\footnotetext{
${ }^{60} \mathrm{See} \mathrm{http://www.myjewishlearning.com/article/kaparot/} \mathrm{and}$ http://www.chabad.org/holidays/JewishNewYear/template_cdo/aid/989585/jewish/Kaparot.htm ${ }_{61}$ «Israel's ultra-Orthodox Rethink Yom Kippur Animal Sacrifice », October 7th, 2011, Haaretz, accessible at: http://www.haaretz.com/jewish/israel-s-ultra-orthodox-rethink-yom-kippur-animal-sacrifice-1.388636 62 « For centuries, the custom of kapparot has been part of our tradition on Yom Kippur, » said Agriculture Minister Uri Ariel. «In recent years, we have been putting in an effort to encourage the public to continue this important custom, yet not through chickens that are transported to slaughter, but instead by donating money. It is right two times - once from the standpoint of preventing cruelty to animals, and again by giving tzedaka to those in need. »

« Agriculture Ministry Introduces Campaign Against Kaparot Ritual », by Sharon Udasin, October 1st, 2016, The Jerusalem Post, accessible at: http://www.jpost.com/Business-and-Innovation/Environment/Agriculture-Ministry-introduces-campaignagainst-kaparot-ritual-469249

See video here: https://youtu.be/KkJoeIM6yXo

63 « Petah Tikva, RIshon Letzion ban kaparot in public places », by Haim Lev, October 10th, 2016, Arutz Sheva, accessible at: http://www.israelnationalnews.com/News/News.aspx/218846

${ }_{64}$ The religious regulations governing the slaughter of animals, proscribing killing the animal by cutting its throat using a sharpened knife.
} 
the Rabbinical Committee on Jewish Law banned the "shackling and hoisting » 65 method of slaughtering in 2000, as it violates the Jewish laws forbidding the causing of unnecessary suffering to animals. Notably, shehita was discussed in a book from the 13th century anonymously published in Spain, known as Sefer haChinnukh, and considered to be designed for minimising animal suffering.

Israel's Ministry of Agriculture went one step further by banning the import of meat in cases where the animals were considered to be slaughtered inhumanely, 66 from June 1st, 2018. This relates primarily to produce that comes from South American slaughterhouses.

After investigations were aired on television, two slaughterhouses were shut down amid increasing scandals over meat production, factory-farming and ritual slaughter in Israel67, in conjunction with concern for animal conditions during live shipment.

One report showed workers at the Deir al-Assad kosher meat factory in northern Israel - the largest in the country - beating the animals in an effort to hurry them toward slaughter. The men were seen to be kicking and hitting the cattle with sticks, dragging them across the floor by their legs, and repeatedly hitting them with a metal gate to push them forward; the workers were fired, however instead of condemning the system itself, the reason given was that they acted against the policies of the company. It is for this reason that amendments that target those with most responsibility in companies is essential; it is very easy to fire the workers every time a scandal goes viral, however it would be of far more benefit to improve the practices and punish those who are aware of the abuse and who overlook it in favour of profit.

One month later, another television report showed workers at Soglowek facility in Shlomi, bashing and kicking chickens, dunking the birds into trash cans while still alive and, using them as makeshift weapons in fights; the slaughterhouse was then shut down 68 .

Is meat even kosher ${ }^{69}$ some ask, considering current animal suffering to conflict with the principles of animal compassion in Judaism. David Rosen, former Senior Rabbi of the largest Orthodox Jewish congregation in South Africa and Chief Rabbi of Ireland, currently American Jewish Committees International Director of

\footnotetext{
${ }^{65}$ Pulling the animal, while conscious, in the air with a chain before cutting its throat.

66 « As Israel bans « schackle and hoist » slaughter, activists ask: What about the US? », by Yaakov Schwartz, May 23rd, 2017, The Times of Israel, accessible at: http://www.timesofisrael.com/as-israelbans-shackle-and-hoist-slaughter-activists-ask-what-about-the-us/

67 «Slaughterhouse ordered offline amid TV cattle abuse scandal », June 10th, 2015, The Times of Israel, accessible at: http://www.timesofisrael.com/slaughterhouse-ordered-offline-amid-tv-cattle-abuse-scandal/ 68 «Second slaughterhouse shuttered over animal cruelty », July 7th, 2015, The Times of Israel, accessible at: http://www.timesofisrael.com/second-slaughterhouse-shuttered-over-animal-cruelty/ 69 «Is any meat today kosher? », by Rabbi David Rosen on his blog, March 16th, 2017, The Times of Israel, accessible at: http://blogs.timesofisrael.com/is-any-meat-today-kosher/
} 
Interreligious Affairs in Jerusalem, makes the powerful argument that kashrut involves more than the way an animal's throat is cut and the checking of vital organs: it involves the whole relationship between humans and the animal world. Indeed " the mitzvot were only given in order to refine people ${ }^{70}$. Thus Rosen asks: «If at point $Z$ the animal's throat was cut the right way and its internal organs checked, but from $A$ to $Y$ all injunctions and prohibitions have been ignored and desecrated, how can that product really be called kosher?»

\section{iii. Live Shipments}

Another negative point of animal welfare in Israel is the transport, including specifically the import of a large number of animals - live shipments - from European countries and Australia, which often entails horrible and long journeys in terrible conditions for the animals. Hence, a lot of protests are going on in the streets of TelAviv and Jerusalem to denounce their suffering ${ }^{71}$, led by organizations such as Israel Against Live Shipments ${ }^{72}$. A petition was launched 3 years ago to end the live shipments to the city of Eilat $^{73}$.

To this regard, Member of Knesset Zandberg submitted a bill to stop such shipments ${ }^{74}$. Efforts are also being sought at international level through international treaties. Additionally, judges recently discussed a petition presented to the court by animal rights groups Anonymous for the Animals and Let the Animals Live, asking that the shipments of live animals to Israel for slaughter be stopped. Judges concluded that not the market, consumer demand nor costs allowed for banning the import of live animals altogether in their interim opinion, pending an update from the government on the implementation of policies to reduce the suffering of animals during transport 75 .

To minimize the suffering of animals imported for slaughter, MK Eitan Broshi from the Zionist Union will soon submit a bill to restrict live cattle shipments to Israel, with the goal of enabling journeys of six days or less only, while ensuring that air transport can not exceed 6 hours $^{76}$, however animal defence organizations argue

\footnotetext{
${ }^{70}$ Genesis Rabbah, 34; Leviticus Rabbah, 13.

${ }^{71}$ «Stop shipments of live animals to Israel for slaughter, protesters urge court » in The Times of Israel, January 31st, 2017, accessible at:

http://www.timesofisrael.com/stop-shipments-of-live-animals-to-israel-for-slaughter-protesters-urgecourt/

${ }^{72} \mathrm{https}: / / \mathrm{m}$. facebook.com/IsraelAgainstLiveShipments

${ }^{73}$ https://www.change.org/p/uzi-landau-end-all-live-shipments-to-eilat-our-tourist-city-in-israel-stop-theunbearable-stench-from-maggots-feces-and-rotting-animal-bodies

${ }^{74} \mathrm{https}: / / \mathrm{www} . k n e s s e t . g o v . i \mathrm{l} /$ spokesman/eng/PR eng.asp?PRID=12185

75 « Court orders reduced suffering in animal shipment », by Sue Surkes, February 3rd, 2017, The Times of Israel, accessible at:

http://www.timesofisrael.com/court-orders-government-to-reduce-suffering-on-animal-shipments/

76 «Legislation to Restrict Live Cattle Imports Underway », June 8th, 2017, The Cattle Site, accessible at: http://www.thecattlesite.com/news/51543/legislation-to-restrict-live-cattle-imports-underway/
} 
it would be both inefficient and ineffective, and instead call for a total ban on live shipments.

More than $30 \%$ of the animals arrive from Australia, a large supplier of the cattle on the Israeli market and world's biggest live animal exporter. The rest of the imports come mainly from Eastern Europe and Portugal. Australia demands fair and humane treatment of the animals even after they have left its territory. After becoming aware of the footage of abused animals, Australian officials demanded an investigation by the Israeli Agriculture Ministry.

Australian veterinarian Lynn Simpson, who served as the official on-board vet for 57 live export journeys, including to Israel, published a report describing animals in cramped conditions, passing the journey covered in their own excrement, calves " cooking from the inside» in the boiling temperatures of the Red Sea, and animal corpses being tossed into the ocean ${ }^{77}$.

\section{The future of religious and legal consideration of animals: veganism?}

From the vegetarian diet at the time of the Creation, to medieval scholars such as Joseph Albo or Isaac Arama regarding vegetarianism as a moral ideal, a school of thought has emerged in Judaism, incarnated in the modern era by such figures as Richard H. Schwartz, author of Judaism and Vegetarianism ${ }^{78}$, stating that God's original plan was for mankind to be vegetarian, as stated in Genesis 1:29. Some also assert that the prophet Isaiah was vegetarian, while Daniel, Shadrach, Meshach and Abednego were vegan according to the Bible ${ }^{79}$, which also states that they were in better health than those eating a non-vegan diet. Several prominent rabbis such as Abraham Isaac Kook or his disciple Rabbi David Cohen - author of A Vision of Vegetarianism and Peace ${ }^{80}$ - also advocated a vegetarian lifestyle.

Indeed, arguments for a vegan diet can be found in both tzaar ba'alei chayim and bal tashchit principles as, on the one side, it spares animal suffering, and on the other side, it is the least wasteful compared to other diets. It is worth mentioning another fundamental principle is the one of maintaining oneself in good health, venishmartem meod lenafshoteichem, leading to the same promotion of a vegan diet,

\footnotetext{
${ }^{77} \mathrm{https}$ ///www.rspca.org.au/uploads/ASEL-Submission-Dr-Lynn-Simpson_web.pdf

${ }^{78}$ Richard H. Schwartz, Judasim and Vegetarianism, Lantern Books, New York, 2001, accessible at: https://www.jewishveg.org/JudaismAndVegetarianism/JudaismandVegetarianism2001.pdf

${ }^{79}$ Daniel 1:8-16

${ }^{80}$ Rav Avraham Yitzhak Hacohen Kook, A Vision of Vegetarianism and Peace, available at https://www.jewishveg.org/AVisionofVegetarianismandPeace.pdf
} 
as animal products are regarded to be, as science increasingly supports, detrimental to human health ${ }^{81}$. It has even been said that the complexity of the kashrut was meant to discourage the eating of meat.

As a matter of fact, it seems doubtful that the Torah would sanction factoryfarming, as this method of raising animals treats them as machines as, underlined by Rabbi Aryeh Carmell, and not as living, sentient beings created by God. For this reason, Conservative Judaism among others advises people to not buy products from intensive factory-farms, as they do not respect animals' capacity to experience enjoyment or suffering, and thus deprive animals of their natural life. It follows that adopting a vegan way of life is a valid personal and religious choice as veganism is consistent with the teachings and ideals of Judaism, while mass production and consumption of animal products contradict many Jewish values. Indeed, religion plays a prominent role in Israeli life; Jewish dietary laws and how they relate to animals, and the way they are killed in factories does not align with the Torah.

Even the Israeli army now acknowledges this ethical lifestyle and provides for vegan meals and clothes ${ }^{82}$ due to the growing number of vegans in the Israeli population. Indeed, surveys generally estimate that around $13 \%$ of Israelis are vegetarians or vegans as of the current data available from $2015^{83}$, with more than 400 food establishments certified « vegan friendly » in Tel-Aviv, including Domino's Pizza, the first in the global chain to sell vegan pizza topped with non-dairy cheese ${ }^{84}$. Israel is home to the largest percentage of vegans per capita in the world and renewed surveys would definitely witness an even higher percentage.

Last but not least, Israel is host to the on-going and indeed promising research on cultured meat - the future of humane meat - as means to replace the « necessity » - if any - of mistreating, exploiting and killing animals. Cultured meat entails the growing of animal cells separate from any living being, with the aim of getting rid of the need to raise and kill animals for food anymore, thus avoiding the causing of suffering. In addition to this, it has powerful and crucial environmental implications, and the potential for fighting world hunger. The Modern Agriculture

\footnotetext{
81 «Diets high in meat, eggs and dairy could be as harmful to health as smoking » in The Guardian, March 5th, 2014, accessible at:

https://www.theguardian.com/science/2014/mar/04/animal-protein-diets-smoking-meat-eggs-dairy

82 «IDF adopts new, vegan-friendly menu », February 1st, 2015, The Times of Israel, accessible at: http://www.timesofisrael.com/idf-adopts-new-vegan-friendly-menu/

«Cutting Edge Army: IDF issues Vegan combat rations, shoes, berets », May 31st, 2016, The Jewish Press, accessible at:

http://www.jewishpress.com/news/breaking-news/cutting-edge-army-idf-issues-vegan-combat-rationsshoes-berets/2016/05/31/

${ }^{83} \mathrm{http} / / /$ www.wow.com/wiki/Vegetarianism_by_country\#Israel

${ }^{84}$ «In the Land of Milk and Honey, Israelis turn Vegan », by Tova Cohen, July 21st, 2015, Reuters, accessible at:

http://www.reuters.com/article/us-israel-food-vegan-idUSKCNOPV1H020150721
} 
Foundation (MAF) ${ }^{85}$ is first company in the world to research mass production of cultured chicken breast deriving from a single cell of a real bird. What if fairly priced cultured meat could satisfy the world's growing demand for meat while eliminating the ethical and environmental problems of raising animals for food? Would we have an ethical problem getting rid of this ethical problem? MAF cofounder, Shir Friedman, argues that everybody becoming vegan would be what the world needs, but this is not realistic; hence when they heard about cultured meat, they " realized this is a way to reduce harm to animals and the environment while giving people the meat they want to eat ${ }^{86}$. Rabbinic authorities consulted by MAF moreover believe cultured chicken will be inherently kosher.

\section{Conclusion on the current protection of animals in Israel}

Animals are (still) considered to be property in Israel, as everywhere in the world. The law is well implemented when it comes to individuals abusing animals, yet industries at the root of cruelty that make profit from the abusive exploitation of animals still remain unpunished and out of reach, for there are currently no means for animal protection organizations to introduce actions on behalf of animals exploited by industries. Indeed, the food industry seems to be the major obstacle blocking the improvement of animal welfare and animal rights in Israel - a case where it is still largely agreed and accepted that human economic and social interests in animal products - mainly food - are legitimate, despite being challenged on a more regular basis as more and more people become vegan. In consideration of these shortcomings, a commission was created to ensure welfare requirements at all stages of animals raised for food's lives according to Jewish ethical values, beyond the time of their slaughter deemed to be the humanest possible. The Heksher Tzedek Commission hence created the Magen Tzedek Seal, visible on kosher products that meet the Commission's standards, the world's first certification of the kind, to ensure the avoidance of gratuitous animal suffering before and during slaughter.

The strongest basis for animal welfare is found in Jewish law, with the Jewish principle of tzaar ba'alei chayim which means «the suffering of living creatures » forbidding unjustified cruelty, or causing unnecessary pain to animals as a biblical mandate commonly accepted by the Talmud ${ }^{87}$. Kashrut, at the very least, requires the humane slaughter of the animal. A further step ahead has been taken in this

\footnotetext{
${ }^{85}$ http://www.futuremeat.org

${ }^{86}$ « Coming soon: chicken meat without slaughter », by Abigail Klein Leichman, November 19th, 2015, Israel 21c, accessible at:

https://www.israel21c.org/coming-soon-chicken-meat-without-slaughter/

${ }^{87}$ The Talmud is the central text of Judaism.
} 


\section{dA derecho ANIMAL}

la web center de los animales con derecho

regard with the Ministry of Agriculture ordering the equipment and monitoring of slaughterhouses with $24 / 7$ video cameras amid scandals ${ }^{88}$, a year before France just decided to do so and only as an experimental provisory measure ${ }^{89}$. Could the gap between animal welfare (implementation of animal welfare basic Jewish principles) and animal rights (putting an end to the slaughtering at all) be closed by to a cautious, selective and animal-friendly interpretation of Jewish Laws that, historically, have put human interests first, by trumping the speciesism that has been inherent to most religious interpretations? A bridge could be under construction under the lead of vegan Orthodox, Conservative and Reform rabbis, hand in hand with secular views and democratic activism, for non-human animals interests to override human greed, as nothing ever seems impossible even in the land of milk and honey.

By drawing a comparison with Man's dignity himself in infringement of nonhuman animals' dignity, the Supreme Court of Israel might have found the way to animals' fundamental right: the dignity of a living creature of God. A nation that made human dignity the Basic Law on which the State is founded provides hope for favorable interpretations of the law on the ground of a potential extension of the concept of dignity to all sentient beings. Last but not least, it is believed that with the arrival of the Messiah, humanity will go back to being vegetarian ${ }^{90}$.

\footnotetext{
${ }^{88}$ http://www.peta.org/blog/israel-orders-slaughterhouses-to-install-cameras/

89 « France passes historic bill requiring all slaughterhouses to be equipped with cameras », January 16th, 2017, Collective Evolution, accessible at:

http://www.collective-evolution.com/2017/01/16/france-passes-historic-bill-requiring-all-

slaughterhouses-to-be-equipped-with-cameras/

${ }^{90}$ Isaiah 11:9
} 


\section{References}

\section{Biblical references}

Talmud

Genesis

Genesis Rabbah

Exodus

Deuteronomy

Leviticus

Leviticus Rabbah

Jeremiah

Isaiah

Samuel

Daniel

Judges

Noahide Laws (Seven Laws)

\section{Books, Articles and Reports}

Anonymous, Sefer haChinnukh, unknown, 13th century

Moses Maimonides, A Guide for the Perplexed, translated from the original Arabic text (1186) by M. Friedlaender, 4th revised ed., New York: E.P. Dutton, 1904

Rav Avraham Yitzhak Hacohen Kook, A Vision of Vegetarianism and Peace, available at https://www.jewishveg.org/AVisionofVegetarianismandPeace.pdf

Richard H. Schwartz, Judasim and Vegetarianism, Lantern Books, New York, 2001, available at https://www.jewishveg.org/JudaismAndVegetarianism/JudaismandVegetarianism2001.pdf

Z. Levi \& N. Levi, Ethics, Feelings, and Animals: The Moral Status of Animals, 2002 


\section{dA derecho ANIMAL la web center de los animales con derecho}

Y. Wolfson, The Moral and Legal Status of Animals, 5 Law and Government 551, 2000

R. Lockwood, Animal Cruelty and Violence Against Humans: Making the Connection, 5 Animal Law 82,1999

Simpson's report, available at https://www.rspca.org.au/uploads/ASEL-Submission-Dr-LynnSimpson_web.pdf

\section{Legislation}

International Whaling Commission

CITES

Constitution of Egypt

Criminal Code of Egypt

Basic Laws of Israel

Criminal Code of Israel

Animal Protection Law on Cruelty to Animals

Animal Protection Law on Animal Experiments

Wildlife Protection Law

Fisheries Ordinance

National Parks, Nature Reserves, National Sites and Memorial Sites Law

Rabies ordinance

Animal Diseases ordinance

Cruelty to Animals Regulations on geese force-feeding

Dog Supervision Law

Prohibition on Declawing Cats

\section{Jurisprudence}

Noah- The Israeli Federation of Animal Protection Organizations v The Attorney-General, The Minister of Agriculture, The Egg and Poultry Board, Moshe Benishty and others, "Foie Gras Verdict », 
Supreme Court of Israel, August 11th, 2003, accessible at http://elyon1.court.gov.il/files eng/01/320/092/S14/01092320.s14.pdf

Let the animals live v Hamat Gader Recreation Enterprises, Tony Loten, Kibbutz Afik, Kibbutz Meitar, Kibbutz Mavo Hama, Kibbutz Kfar Haruv, Court of Civil Appeals, June 22nd, 1997

The Cat Welfare Society of Israel v. Municipality of Arad, Supreme Court of Israel, 1996, HCJ $6446 / 96$

\section{Newspapers}

France passes historic bill requiring all slaughterhouses to be equipped with cameras, January 16th, 2017,Collective Evolution http://www.collective-evolution.com/2017/01/16/france-passes-historic-bill-requiring-allslaughterhouses-to-be-equipped-with-cameras/

Coming soon: chicken meat without slaughter, by Abigail Klein Leichman, November 19th, 2015, Israel 21c

https://www.israel21c.org/coming-soon-chicken-meat-without-slaughter/

In the Land of Milk and Honey, Israelis turn Vegan, by Tova Cohen, July 21st, 2015, Reuters http://www.reuters.com/article/us-israel-food-vegan-idUSKCNOPV1H020150721

IDF adopts new, vegan-friendly menu, February 1st, 2015, The Times of Israel http://www.timesofisrael.com/idf-adopts-new-vegan-friendly-menu/

Cutting Edge Army: IDF issues Vegan combat rations, shoes, berets, May 31st, 2016, The Jewish Press

http://www.jewishpress.com/news/breaking-news/cutting-edge-army-idf-issues-vegan-combatrations-shoes-berets/2016/05/31/

Diets high in meat, eggs and dairy could be as harmful to health as smoking, March 5th, 2014, The Guardian

https://www.theguardian.com/science/2014/mar/04/animal-protein-diets-smoking-meat-eggsdairy

Legislation to Restrict Live Cattle Imports Underway, June 8th, 2017, The Cattle Site http://www.thecattlesite.com/news/51543/legislation-to-restrict-live-cattle-imports-underway/

Court orders reduced suffering in animal shipment, by Sue Surkes, February 3rd, 2017, The Times of Israel

http://www.timesofisrael.com/court-orders-government-to-reduce-suffering-on-animalshipments/

Stop shipments of live animals to Israel for slaughter, protesters urge court, January 31st, 2017, The Times of Israel http://www.timesofisrael.com/stop-shipments-of-live-animals-to-israel-for-slaughter-protestersurge-court/ 
Is any meat today kosher? by Rabbi David Rosen on his blog, March 16th, 2017, The Times of Israel http://blogs.timesofisrael.com/is-any-meat-today-kosher/

Second slaughterhouse shuttered over animal cruelty, July 7th, 2015, The Times of Israel http://www.timesofisrael.com/second-slaughterhouse-shuttered-over-animal-cruelty/

Slaughterhouse ordered offline amid TV cattle abuse scandal, June 10th, 2015, The Times of Israel http://www.timesofisrael.com/slaughterhouse-ordered-offline-amid-tv-cattle-abuse-scandal/

As Israel bans « schackle and hoist » slaughter, activists ask: What about the US?, by Yaakov Schwartz, May 23rd, 2017, The Times of Israel

http://www.timesofisrael.com/as-israel-bans-shackle-and-hoist-slaughter-activists-ask-whatabout-the-us/

Petah Tikva, RIshon Letzion ban kaparot in public places, by Haim Lev, October 10th, 2016, Arutz Sheva

http://www.israelnationalnews.com/News/News.aspx/218846

Agriculture Ministry Introduces Campaign Against Kaparot Ritual, by Sharon Udasin, October 1st, 2016, The Jerusalem Post

http://www.jpost.com/Business-and-Innovation/Environment/Agriculture-Ministry-introducescampaign-against-kaparot-ritual-469249

Israel's ultra-Orthodox Rethink Yom Kippur Animal Sacrifice, October 7th, 2011, Haaretz http://www.haaretz.com/jewish/israel-s-ultra-orthodox-rethink-yom-kippur-animal-sacrifice$\underline{1.388636}$

In Israel, declawing your cat could get you jail time, December 9th, 2011, Time http://newsfeed.time.com/2011/12/09/declawing-your-cat-could-get-you-a-year-in-jail-in-israel/

Knesset approves strict amendments to animal welfare law in first reading, by Sharon Udasin, July 28th, 2015, The Jerusalem Post http://www.jpost.com/Israel-News/Knesset-approves-strict-amendments-to-Animal-WelfareLaw-in-first-reading-410426

Knesset passes stricter animal rights measures: more jail time, increased fines for violators, by Sharon Udasin, December 15th, 2015, The Jerusalem Post http://www.jpost.com/Israel-News/Politics-And-Diplomacy/Knesset-passes-stricter-animalrights-measures-More-jail-time-increased-fines-for-violators-437396

Animal Welfare Enforcement to Remain in Agriculture Ministry, by Sharon Udasin, December 14th, 2015, The Jerusalem Post http://www.jpost.com/Israel-News/Animal-welfare-enforcement-to-remain-in-AgricultureMinistry-437247

If you want to stop violence against people, Stop violence against animals, by Lynne Peeples, August 10th, 2015, The Huffington Post: 
http://www.huffingtonpost.com/entry/animal-abuse-human-violencelink us 560f2269e4b0af3706e0fd5b

The Land of Milk: Israel's Super Cows are the World's Most Productive, by Joshua Levitt, March 11th, 2014, The Algemeiner https://www.algemeiner.com/2014/03/11/the-land-of-milk-israels-super-cows-are-the-worldsmost-productive-video/

The Brutal Reality Behind Israel's Egg and Poultry Quotas, by Orna Rinat, December 29th, 2015, Haaretz

http://www.haaretz.com/opinion/.premium-1.694293

The Israeli Calf that started a Mass Tattoo Movement, by Netta Ahituv, March 21st, 2013, Haaretz http://www.haaretz.com/israel-news/the-israeli-calf-that-started-a-mass-tattoomovement.premium-1.511045

«Thousands flock to mass Tel Aviv rally for Animal Rights », by Daniel K. Eisenbud, September 10, 2017, The Jerusalem Post http://www.jpost.com/Israel-News/WATCH-Thousands-flock-to-mass-Tel-Aviv-rally-for-animalrights-504657

«In Israel, Man's best friend is also his most expensive friend », by Hadar Kane, January 6, 2017, Haaretz https://www.haaretz.com/israel-news/business/1.763359

«Ask the Rabbi: neutering animals », by Schlomo Brody, May 14, 2009, The Jerusalem Post, accessible at: http://www.jpost.com/Jewish-World/Judaism/Ask-the-Rabbi-Neutering-animals

«Feral cats in Israel», CHAI Factsheet, accessible at: http://www.chai.org.il/en/companion/overpopulation feral.htm

«Israel plans mass spaying campaign to combat street cat proliferation », by Sharon Udasin, October 28, 2013, The Jerusalem Post, accessible at: http://www.jpost.com/Enviro-Tech/Israel-plans-massspaying-campaign-to-combat-street-cat-proliferation-329973

"Scrambling every day: Stray cats struggle to survive in Jerusalem », by Derek Stoffel, August 27, 2016, CBC News, accessible at: http://www.cbc.ca/news/world/jerusalem-stray-cats-1.3732282

"In groundbreaking move, Israel creates budget to fix stray dogs rather than putting them down », by Jonathan Lis, March 22, 2017, Haaretz, accessible at: https://www.haaretz.com/israelnews $/ 1.778818$

\section{Videos}

Records from the animal rights march in Tel Aviv, September 2017, accessible at: https://www.youtube.com/watch?v=Ul0RYK-9BqE.

Government's campaign against kaparot, accessible at https://youtu.be/KkJoeIM6yXo 
Hai Meshek's videos, accessible at https://www.youtube.com/watch?v=fx3FbpYLOno and https://www.youtube.com/watch?v=82Lh6by8EPs

« Best Speech Ever », Gary Yourofsky, accessible at https://www.youtube.com/watch?v=omweihtaYwI\&feature=youtu.be

\section{Websites}

Knesset http://main.knesset.gov.il/Pages/default.aspx

Supreme Court of Israel http://elyon1.court.gov.il/eng/home/index.html

Israel Ministry of Foreign Affairs http://mfa.gov.il

Israel Ministry of Environment http://www.sviva.gov.il/English/Pages/HomePage.aspx

Ministry of Agriculture http://www.moag.gov.il/Pages/HomePage.aspx

Academy of Sciences and Humanities http://www.academy.ac.il/?nodeId=808

Heksher Tzedek Commission http://www.magentzedek.org/

Facebook http://www.facebook.com

Youtube http://www.youtube.com

Channel 2 News http://www.mako.co.il/news-channel2/the-english-edition

Channel 10 News http://www.nana10.co.il/

Chabad chabad.org

MyJewishLearning myjewishlearning.com

ReformJudaism reformjudaism.org

Animal Law Legal and Historical Center, Michigan State University https://www.animallaw.info/

Global Animal Law Project globalanimallaw.org

PETA peta.org

HSUS humanesociety.org

Israel Against Live Shipments https://m.facebook.com/IsraelAgainstLiveShipments 


\section{dA derecho ANIMAL la web center de los animales con derecho}

Anonymous for the Animals Israel http://www.anonymous.org.il

Let The Animals Live http://www.letlive.org.il/eng/

269Life http://www.269life.com/\#\&panel1-1

CHAI chai-online.org

SPCA Israel http://spca.co.il/newsite/page en.asp?p id=41

Hai-Meshek http://www.hai-meshek.org.il/?page id=335

Modern Agricultural Foundation http://www.futuremeat.org

Change Organization http://www.change.org

WOW - http://www.wow.com 